Article

\title{
Hydrothermal Enhanced Nanoscale Zero-Valent Iron Activated Peroxydisulfate Oxidation of Chloramphenicol in Aqueous Solutions: Fe-Speciation Analysis and Modeling Optimization
}

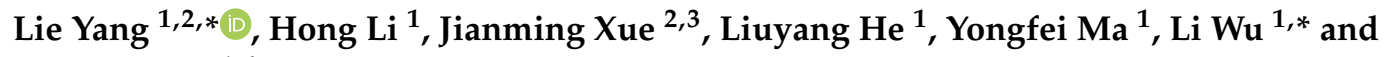 \\ Zulin Zhang 1,4,* \\ 1 Hubei Key Laboratory of Mineral Resources Processing and Environment, School of Resources and \\ Environmental Engineering, Wuhan University of Technology, Wuhan 430070, China; \\ Lihong516@whut.edu.cn (H.L.); lyh1994@whut.edu.cn (L.H.); yongfei.ma@whut.edu.cn (Y.M.) \\ 2 Scion, Christchurch 8440, P.O. Box 29237, New Zealand; jianming.xue@scionresearch.com \\ 3 College of Biology and the Environment, Nanjing Forestry University, Nanjing 210037, China \\ 4 The James Hutton Institute, Craigiebuckler, Aberdeen ABI5 8QH, UK \\ * Correspondence: yanglie612@whut.edu.cn (L.Y.); wuli774@whut.edu.cn (L.W.); \\ Zulin.Zhang@hutton.ac.uk (Z.Z.)
}

Received: 26 November 2019; Accepted: 28 December 2019; Published: 31 December 2019

\begin{abstract}
The efficiencies of the nanoscale zero-valent iron (nZVI) and hydrothermal and nZVI-heat activation of peroxydisulfate (PS) were studied for the decomposition of chloramphenicol (CAP) in aqueous solutions. The nZVI heat combined with activation of PS provided a significant synergistic effect. A central composite design (CCD) with response surface methodology (RSM) was employed to explore the influences of single parameter and interactions of selected variables (initial $\mathrm{pH}, \mathrm{PS}$ concentration, nZVI and temperature) on degradation rates with the purpose of condition optimization. A quadratic model was established based on the experimental results with excellent correlation coefficients of 0.9908 and 0.9823 for $R^{2}$ and $R^{2}$ adj. The optimized experimental condition for $97.12 \%$ CAP removal was predicted with the quadratic model as $15 \mathrm{mg} / \mathrm{L}, 0.5 \mathrm{mmol} / \mathrm{L}, 7.08$ and $70{ }^{\circ} \mathrm{C}$ for nZVI dosage, PS, initial $\mathrm{pH}$, and temperature, respectively. This study demonstrated the effectiveness of RSM for the modeling and prediction of CAP removal processes. In the optimal condition, $\mathrm{Fe}_{2} \mathrm{O}_{3}$ and $\mathrm{Fe}_{3} \mathrm{O}_{4}$ were the predominant solid products after reactions based on X-ray photoelectron spectroscopy (XPS) and X-ray diffraction (XRD) analysis, which could also act as the activators along with the reaction. Overall, it could be concluded that hydrothermal enhanced nZVI activation of PS was a promising and efficient choice for CAP degradation.
\end{abstract}

Keywords: persulfate; nZVI; chloramphenicol; Fe species; response surface methodology

\section{Introduction}

Since the 1950s chloramphenicol (CAP) has acted as a widely applied broad-spectrum antibiotic with excellent antibacterial properties [1-3]. Approximately $16 \%$ to $38 \%$ of CAP potentially leaves organisms as a form of parent compound through feces or urine before being discharged into sewage [4]. It was reported that CAP was not effectively removed by traditional wastewater plants and largely reached surface waters, causing notable ecological risks [5,6]. CAP concentrations of up to $28.36 \mathrm{ng} \cdot \mathrm{L}^{-1}$ have been found in urban water supplies of Shanghai, China [7]. The concentrations of CAP in raw wastewater and biologically treated wastewater were reported as $38.84 \pm 44.74 \mathrm{mg} \cdot \mathrm{L}^{-1}$ and $21.24 \pm 15.74 \mathrm{mg} \cdot \mathrm{L}^{-1}$, respectively [8]. Its negative effects, such as bone marrow suppression and 
aplastic anemia cannot be ignored, [9], as they pose a notable threat to human health [10]. Thus, novel techniques are urgently needed for efficient CAP removal.

There have been some techniques applied for CAP removal from aqueous solution, such as adsorption [11-15], nano materials [16-19], electrochemistry [20,21], and advanced oxidation processes [8]. Among them, persulfate (PS) has, in recent years, attracted great attention as an alternative to $\mathrm{H}_{2} \mathrm{O}_{2}$ for advanced oxidation processes due to its high redox potential $(2.5 \mathrm{~V}-3.1 \mathrm{~V})$ and longer lifetime than ${ }^{\bullet} \mathrm{OH}$ [22-24]. Moreover, PS has the advantage of convenient storage and delivery in the form of solid particles due to its stability in the inactive state [22] and its longevity. It is also non-selective for degradation of a variety of contaminants [25]. There are a series of available methods for PS activation [25]. It is worth mentioning that nanoscale zero-valent iron (nZVI) activation has attracted increasing attention due to its combined effects of $\mathrm{Fe}^{0}, \mathrm{Fe}^{2+}, \mathrm{Fe}^{3+}, \mathrm{FeOOH}$, and $\mathrm{Fe}_{3} \mathrm{O}_{4}$ [26]. Furthermore, nZVI has been verified to be capable for decomposing organic pollutants through the reaction with dissolved oxygen to generate ${ }^{\bullet} \mathrm{OH}, \mathrm{O}_{2}{ }^{\bullet}$, and $\mathrm{HO}_{2}{ }^{\bullet}[27,28]$. Thus, nZVI-activated PS oxidation could act as a potential choice for CAP removal. As for reaction rate improvement, reaction temperature is a crucial operational variable for aqueous viscosity [29] and mass transfer coefficients [30]. As the temperature increases, heat energy can also act as a persulfate activator to increase the $\mathrm{SO}_{4}{ }^{-\bullet}$ radicals [31]. Hydrothermal enhanced degradation of CAP using nZVI-activated PS oxidation was investigated in this study. Response surface methodology (RSM), a widely used optimized tool [32-34], was used to assess the selected operational variables based on a proposed quadratic model. The main aims of this study were to: (1) investigate the synergistic effects of a heat/nZVI combined activation of PS on CAP removal and (2) optimize the operational conditions of CAP degradation based on a proposed quadratic model.

\section{Material and Methods}

\subsection{Materials}

Chloramphenicol (analytical grade, 99.2\%) was bought from Dr. Ehrenstorfer GmbH. Sodium persulfate $\left(\mathrm{Na}_{2} \mathrm{~S}_{2} \mathrm{O}_{8}, \geq 98 \%\right.$ ) was obtained from Sinopharm Chemical Reagents Co., Ltd. (Shanghai, China). nZVI $(\geq 99.9 \%, 50 \mathrm{~nm})$ was purchased from Hubei Institute of Material Protection. All reagents were of analytical grade and all the solution were prepared with Milli-Q ultrapure water. The physicochemical characteristics and molecular details of CAP are demonstrated in Table $1[6]$.

Table 1. Physicochemical properties of chloramphenicol (CAP) [6].

\begin{tabular}{cc}
\hline Parameter & Character \\
\hline Formula & $\mathrm{C}_{11} \mathrm{H}_{12} \mathrm{Cl}_{2} \mathrm{~N}_{2} \mathrm{O}_{5}$ \\
Molecular weight & 323.13 \\
Solubility $(\mathrm{mg} / \mathrm{L}), 2{ }^{\circ} \mathrm{C}$ & 2500 \\
Log Kow & 1.14 \\
$\mathrm{pK}$ & 9.5 \\
$\mathrm{CAS}$ number & $56-75-7$ \\
Molecular structure &
\end{tabular}

\subsection{Experimental Setup and Analysis Method}

A wide range of CAP concentrations were applied in the other studies, which included $110 \mathrm{mg} / \mathrm{L}$ [17], $10 \mathrm{mg} / \mathrm{L}$ [21], $20 \mathrm{mg} / \mathrm{L}$ [21], and $9.69 \mathrm{mg} / \mathrm{L}$ [35]. In this work, all trials were implemented in glass reaction tanks $(250 \mathrm{~mL})$ containing $100 \mathrm{~mL}$ of CAP solution and the initial concentration 
was $1 \mathrm{mg} / \mathrm{L}$ to simulate a low CAP concentration in wastewater. Before adding PS and nZVI, the reactor with CAP solution was heated in water-bath (HH-4, Changzhou Aohua Instrument Co., Ltd., Changzhou, China) for about $5 \mathrm{~min}$ to reach the required temperature $\left(40-80^{\circ} \mathrm{C}\right)$. The solution was continuously stirred with a mechanical stirrer equipped with Teflon stirring blades (DJ1C-40, Jintandadi, Changzhou, China) during the reaction period. A $4 \mathrm{~cm}$ diameter blade was placed in the middle of each vessel. The stirring speed was maintained at $250 \mathrm{rpm} / \mathrm{min}$ and an entire reaction lasted for $20 \mathrm{~min}$. The solution $\mathrm{pH}$ was adjusted using $0.1 \mathrm{~mol} / \mathrm{L} \mathrm{H}_{2} \mathrm{SO}_{4}$ or $\mathrm{NaOH}$ solution. At selected time points, $1 \mathrm{~mL}$ solution was taken out for further determination and an equal volume of methanol was added into the sample immediately to inhibit CAP oxidation during the determination process. The mixture was filtered through $0.22 \mu \mathrm{m}$ membrane (Jinteng Ltd., Tianjin, China) and prepared for further LC-MS/MS analysis. The CAP concentrations in the reaction system was determined with Q-Sight ${ }^{\mathrm{TM}} 210$ LX50 HPLC (PerkinElmer) coupled to a Triple Quad Mass Spectrometer with electrospray ionization (ESI). A Phenomenex Kinetic C18 100A column (Size $100 \times 4.6 \mathrm{~mm}$; particle size $2.6 \mu \mathrm{m}$ ) and negative ESI mode was used for CAP determination. The column temperature was set as $35^{\circ} \mathrm{C}$, and the injection volume was set as $2 \mu \mathrm{L}$ each time. The mobile phase comprised acetonitrile and water (volume ratio 6:4) and the flow rate was maintained at $0.6 \mathrm{~mL} / \mathrm{min}$. The crystalline structure analysis of mixed powder after reactions was conducted with D8 X-ray diffraction (XRD) spectra (Bruker, Germany). Jade 5.0 software was used to determine the crystalline structure of nZVI surface after reactions. In addition, X-ray photoelectron spectroscopy (XPS) analysis of mixed powder was performed using KRATOS Axis Ultra (Kratos Analytical, Manchester, United Kingdom) and analyzed with XPS peak 41 software (Raymund Kwok, HongKong, China).

\subsection{Experimental Details}

As a widely used method, RSM gives guidance for variable optimization within minimal trial runs by model prediction [36]. In this research, four independent variables were selected and analyzed for the maximal CAP removal from aqueous solution. With a view to exploring the effects of relevant operating variables (initial pH, nZVI dosage, PS concentration, and temperature) on CAP decomposition, the selected vital factors affecting CAP removal rate and the optimal level of interaction were set by central composite design (CCD). For each factor, five levels $(+2,+1,0,-1$, and -2$)$ were applied (Table 2) [33]. Thus a four-factor of five-level CCD design with 30 runs was employed, and the five coded levels of each variable were designated as $-2,-1,0,+1$, and +2 (Table 3). A software named Design-Expert 8.0.6 (State-Ease, Minneapolis, AL, USA) was used to design, analyze, and optimize the experimental model [33]. All experimental data were analyzed by the least-squares regression method to predict the process response and to estimate the coefficients according to a second-order equation [33]. In order to determine the accuracy and adequacy of the prediction model, the appropriate graph of the "actual vs. predicted" values and the graph of the model response and residual application were presented, respectively. The accuracy of proposed equation was examined using the analysis of variance (ANOVA). Model coefficients calculated by multiple regression analysis of experimental data were analyzed to assess whether a given term had a significant effect $(p \leq 0.05)$. These effects were outlined based on a fitting quadratic equation. Eventually, the optimized operating condition was calculated and provided to maximize CAP removal.

Table 2. Experimental arrangements based on central composite design (CCD).

\begin{tabular}{ccccccc}
\hline \multirow{2}{*}{ Factors } & \multirow{2}{*}{ Symbols } & \multicolumn{5}{c}{ Level of Factors } \\
\cline { 3 - 7 } & & $-\mathbf{2}$ & $\mathbf{- 1}$ & $\mathbf{0}$ & $\mathbf{1}$ & $\mathbf{2}$ \\
\hline Nanoscale zero-valent iron (nZVI) $(\mathrm{mg} / \mathrm{L})$ & $\mathrm{X}_{1}$ & 10 & 15 & 20 & 25 & 30 \\
Peroxydisulfate (PS) concentration $(\mathrm{mM})$ & $\mathrm{X}_{2}$ & 0.2 & 0.3 & 0.4 & 0.5 & 0.6 \\
Initial $\mathrm{pH}$ & $\mathrm{X}_{3}$ & 3 & 5 & 7 & 9 & 11 \\
Temperature $\left({ }^{\circ} \mathrm{C}\right)$ & $\mathrm{X}_{4}$ & 40 & 50 & 60 & 70 & 80 \\
\hline
\end{tabular}


Table 3. The 4-factor CCD matrix and the actual values for CAP removal.

\begin{tabular}{|c|c|c|c|c|c|c|}
\hline \multirow{2}{*}{ Run Number } & \multicolumn{4}{|c|}{ Factors } & \multicolumn{2}{|c|}{ Degradation Efficiency (\%) } \\
\hline & $X_{1}$ & $X_{2}$ & $X_{3}$ & $X_{4}$ & Observed & Predicted \\
\hline 1 & 25 & 0.5 & 5 & 50 & 80.72 & 81.82 \\
\hline 2 & 20 & 0.4 & 7 & 80 & 93.07 & 95.84 \\
\hline 3 & 20 & 0.4 & 3 & 60 & 90.62 & 88.90 \\
\hline 4 & 20 & 0.6 & 7 & 60 & 84.76 & 82.45 \\
\hline 5 & 15 & 0.3 & 5 & 50 & 60.93 & 62.96 \\
\hline 6 & 15 & 0.3 & 9 & 50 & 17.42 & 18.36 \\
\hline 7 & 15 & 0.5 & 9 & 70 & 94.95 & 94.64 \\
\hline 8 & 15 & 0.5 & 9 & 50 & 24.45 & 27.15 \\
\hline 9 & 25 & 0.5 & 5 & 70 & 96.25 & 95.02 \\
\hline 10 & 25 & 0.5 & 9 & 70 & 93.54 & 90.88 \\
\hline 11 & 20 & 0.4 & 11 & 60 & 37.52 & 40.16 \\
\hline 12 & 25 & 0.3 & 9 & 70 & 80.11 & 79.40 \\
\hline 13 & 10 & 0.4 & 7 & 60 & 82.83 & 78.58 \\
\hline 14 & 15 & 0.3 & 9 & 70 & 86.62 & 84.89 \\
\hline 15 & 20 & 0.4 & 7 & 60 & 76.42 & 75.47 \\
\hline 16 & 15 & 0.3 & 5 & 70 & 86.76 & 86.53 \\
\hline 17 & 20 & 0.4 & 7 & 40 & 17.97 & 16.12 \\
\hline 18 & 20 & 0.4 & 7 & 60 & 74.80 & 75.47 \\
\hline 19 & 20 & 0.4 & 7 & 60 & 75.61 & 75.47 \\
\hline 20 & 25 & 0.3 & 5 & 70 & 89.03 & 85.70 \\
\hline 21 & 20 & 0.4 & 7 & 60 & 75.70 & 75.47 \\
\hline 22 & 20 & 0.2 & 7 & 60 & 61.12 & 64.35 \\
\hline 23 & 30 & 0.4 & 7 & 60 & 80.16 & 85.33 \\
\hline 24 & 15 & 0.5 & 5 & 50 & 69.16 & 69.58 \\
\hline 25 & 25 & 0.3 & 5 & 50 & 73.46 & 73.48 \\
\hline 26 & 25 & 0.3 & 9 & 50 & 28.59 & 24.22 \\
\hline 27 & 20 & 0.4 & 7 & 60 & 75.51 & 75.47 \\
\hline 28 & 25 & 0.5 & 9 & 50 & 34.79 & 34.73 \\
\hline 29 & 20 & 0.4 & 7 & 60 & 74.77 & 75.47 \\
\hline 30 & 15 & 0.5 & 5 & 70 & 90.38 & 94.12 \\
\hline
\end{tabular}

\section{Results and Discussion}

\subsection{The Synergistic Effect of nZVI-Heat Activated PS Degradation of CAP}

With a view to exploring the synergistic effects, CAP degradation was conducted under various treatments (nZVI, PS, nZVI-PS, heat-PS, and nZVI-heat-PS) with initial CAP concentration of $1 \mathrm{mg} / \mathrm{L}$ and with $20 \mathrm{~min}$ of reaction time. Different CAP degradation efficiencies were obtained in the various processes as demonstrated in Figure 1. The CAP removal efficiencies for nZVI alone and PS alone were only $11.57 \%$ and $10.13 \%$, respectively. As for PS activation processes, $22.60 \%, 42.86 \%$, and $70.89 \%$ were obtained in nZVI-PS, heat-PS, and nZVI-heat-PS processes, respectively. The pseudo-first-order kinetic model (Equation (1)) has been widely used to describe the removal of conventional and emerging organic contaminants [18]. The combined degradation of CAP presented an enhanced degradation rate constant $\left(5.76 \times 10^{-2} \mathrm{~min}^{-1}\right)$ compared with the individual activation processes of $1.18 \times 10^{-2} \mathrm{~min}^{-1}$ and $2.86 \times 10^{-2} \mathrm{~min}^{-1}$ for $\mathrm{nZVI}$ and heat activation, respectively. There is an equation for the calculation of synergistic influences (Equation (2)) [37]. Synergy index values greater than 1.0 indicated a positive synergistic effect of the combined process [36]. In this research, the combined activated PS degradation of CAP showed a synergistic index of 1.43, indicating an excellent performance of nZVI-heat activation. The phenomenon could be ascribed to a series of complicated reactions including radical effects and non-radical effects. The results evidently verified that the nZVI-heat combined activation of PS oxidation is an alternative solution for CAP removal from aqueous solution. 


$$
\ln \left(C_{t} / C_{0}\right)=-k_{\text {obs }} \times t
$$

Synergy index $=\mathrm{k}(\mathrm{nZVI}+$ heat $+\mathrm{PS}) /(\mathrm{k}(\mathrm{nZVI}+\mathrm{PS})+\mathrm{k}($ heat $+\mathrm{PS}))$

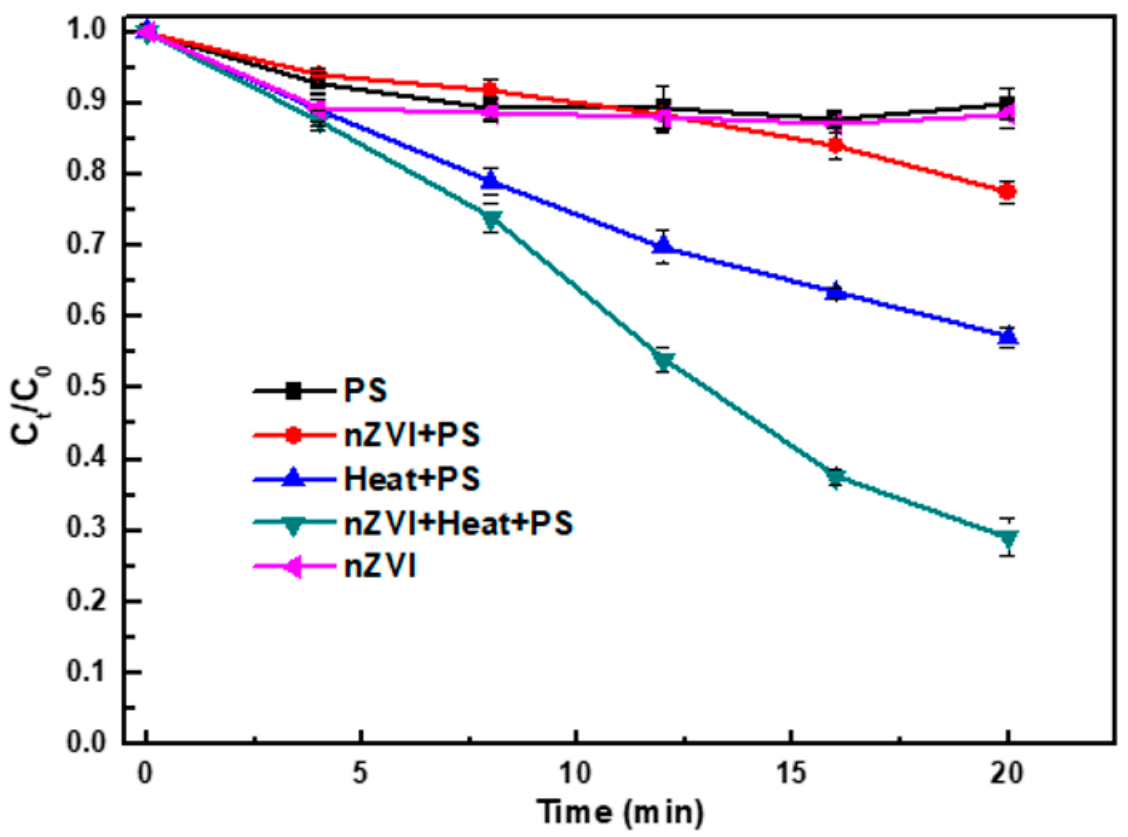

Figure 1. Degradation efficiencies of CAP under different processes. Experimental conditions: initial CAP concentration $\mathrm{C}_{0}=1 \mathrm{mg} / \mathrm{L}, \mathrm{pH}=7.0, \mathrm{nZVI} 20 \mathrm{mg} / \mathrm{L}$, temperature $60^{\circ} \mathrm{C}$, PS concentration $=0.4 \mathrm{mM}$, and the solution volume $100 \mathrm{~mL}$.

\subsection{Model Analysis}

The obtained results were fitted with the proposed model. The multiple regression analysis was applied in RSM and the detailed outcomes of regression analysis of the model for CAP removal were summarized (Table 4). Additionally, the significance of linear, interactive, and quadratic terms could be expressed by $p$-values [33,36]. When $p$-values $<0.05(95 \%)$, the terms could be considered to be significant. Based on the results, it was observed that the obtained coefficients of all the first-order terms $\left(X_{1}, X_{2}, X_{3}\right.$, and $\left.X_{4}\right)$, two interaction terms $\left(X_{1} X_{4}\right.$ and $\left.X_{3} X_{4}\right)$ and three quadratic coefficients $\left(X_{1}{ }^{2}, X_{3}{ }^{2}\right.$, and $\left.\mathrm{X}_{4}{ }^{2}\right)$ were significant $(p<0.05,95 \%)$. The other insignificant term coefficients $(p>0.05,95 \%)$ could be removed from the model due to their insignificant influence on CAP degradation efficiency. As a result, the model was presented in Equation (3) to simulate the CAP degradation efficiency using nZVI + heat + PS processes.

$$
\begin{gathered}
Y=75.47+1.69 X_{1}+4.53 X_{2}-12.18 X_{3}+19.93 X_{4}-2.84 X_{1} X_{4}+10.74 X_{3} X_{4}+1.62 X_{1}^{2}- \\
2.73 X_{3}^{2}-4.87 X_{4}{ }^{2}
\end{gathered}
$$

$Y$ represents the efficiency of CAP degradation. $X_{1}, X_{2}, X_{3}$, and $X_{4}$ represent the terms of $n Z V I(m g)$, PS concentration $(\mathrm{mM})$, initial $\mathrm{pH}$, and temperature $\left({ }^{\circ} \mathrm{C}\right)$, respectively. Generally, positive coefficients $(>0)$ indicate favorable effects on degradation efficiency, whereas negative coefficients $(<0)$ indicate unfavorable effects on degradation efficiency $[36,38]$. Based on data diagnostics, two representative graphs were obtained to verify the accuracy of proposed model. As demonstrated in Figure 2a, the points showed a good linearity and fit well with the normal distribution. According to Figure $2 b$, it was obvious that the predicted model could predict the degradation efficiency accurately. Thus, the established equation is creditable for the simulation of CAP degradation in the control condition. 
Table 4. Significant terms from regression analysis of the proposed model.

\begin{tabular}{cccc}
\hline Term & Coefficient Estimate & Standard Error & $p$-Value \\
\hline Intercept & 75.47 & 1.31 & $<0.0001$ \\
$\mathrm{X}_{1}$ & 1.69 & 0.65 & 0.0208 \\
$\mathrm{X}_{2}$ & 4.53 & 0.65 & $<0.0001$ \\
$\mathrm{X}_{3}$ & -12.18 & 0.65 & $<0.0001$ \\
$\mathrm{X}_{4}$ & 19.93 & 0.65 & $<0.0001$ \\
$\mathrm{X}_{1} \mathrm{X}_{4}$ & -2.84 & 0.80 & 0.0029 \\
$\mathrm{X}_{3} \mathrm{X}_{4}$ & 10.74 & 0.80 & $<0.0001$ \\
$\mathrm{X}_{1}{ }^{2}$ & 1.62 & 0.61 & 0.0181 \\
$\mathrm{X}_{3}{ }^{2}$ & -2.73 & 0.61 & 0.0004 \\
$\mathrm{X}_{4}{ }^{2}$ & -4.87 & 0.61 & $<0.0001$ \\
\hline
\end{tabular}

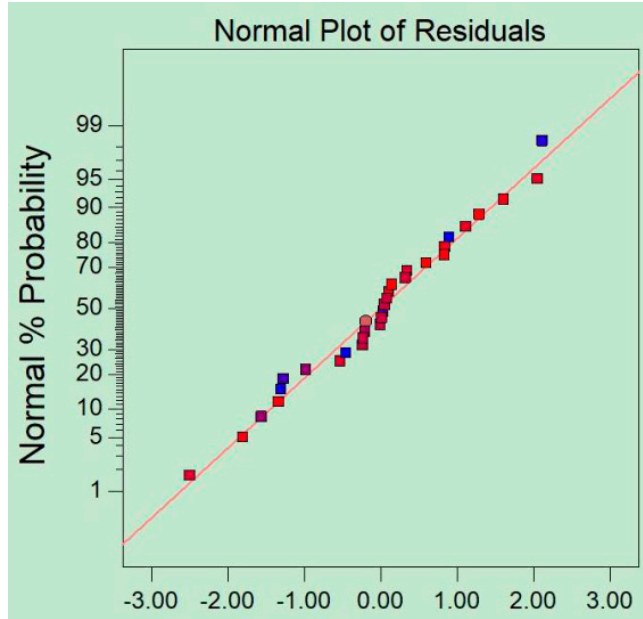

Internally Studentized Residuals

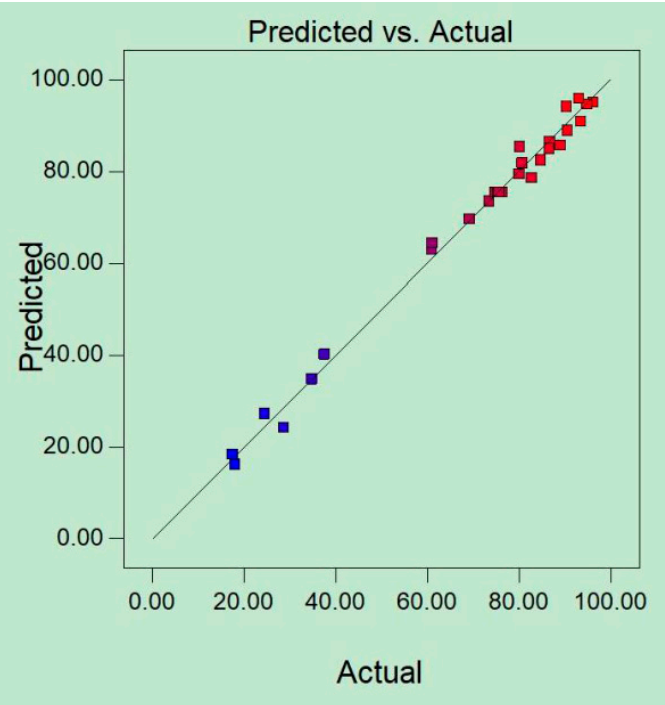

(b)

Figure 2. (a) Normal plot of the internally studentized residuals and (b) actual values versus predicted data for CAP removal.

The detailed statistical information of the established model was analyzed and summarized in Table 5. The crucial parameters (F, P, CV, $\mathrm{R}^{2}$, and $\mathrm{R}^{2}$ adj etc.) were assessed for the validity and accuracy of the proposed model [39-42]. It was observed that Fisher's F-value of 115.86 was much higher than $2.3928\left(\mathrm{~F}_{\text {critical }, 0.05,9,20}\right)$, implying the significance of the proposed model [33,36]. Additionally, the extremely low probability value $(<0.0001)$ could also confirm the significance of the proposed model. Also, the lack-of-fit (LOF) (F-value $0.0004<4.7725)$ and the adequate precision ratio (AP $35.224>4$ ) could confirm the insignificant shortage and sufficient adequacy for the model $[33,36]$. It was reported that low coefficient of variance (CV) $(<10 \%)$ meant satisfactory repeatability of experiments [36]. The CV of this study was $4.55 \%(<10 \%)$ and met the mentioned requirement. The $R^{2}(0.9908)$ and adjusted $\mathrm{R}^{2}(0.9823)$ indicated the model's satisfactory adequacy for the prediction of CAP removal. 
Table 5. Details of the proposed model for the CAP removal.

\begin{tabular}{cccccc}
\hline Term & Squares & df & Square & Value & Probability $>$ F \\
\hline Model & $16,615.92$ & 14 & 1186.85 & 115.86 & $<0.0001$ \\
$\mathrm{X}_{1}$ & 68.28 & 1 & 68.28 & 6.66 & 0.0208 \\
$\mathrm{X}_{2}$ & 491.41 & 1 & 491.41 & 47.97 & $<0.0001$ \\
$\mathrm{X}_{3}$ & 3562.89 & 1 & 3562.89 & 347.80 & $<0.0001$ \\
$\mathrm{X}_{4}$ & 9532.92 & 1 & 9532.92 & 930.57 & $<0.0001$ \\
$\mathrm{X}_{1} \mathrm{X}_{2}$ & 2.98 & 1 & 2.98 & 0.29 & 0.5978 \\
$\mathrm{X}_{1} \mathrm{X}_{3}$ & 21.72 & 1 & 21.72 & 2.12 & 0.1660 \\
$\mathrm{X}_{1} \mathrm{X}_{4}$ & 128.71 & 1 & 128.71 & 12.56 & 0.0029 \\
$\mathrm{X}_{2} \mathrm{X}_{3}$ & 4.69 & 1 & 4.69 & 0.46 & 0.5091 \\
$\mathrm{X}_{2} \mathrm{X}_{4}$ & 0.94 & 1 & 0.94 & 0.092 & 0.7660 \\
$\mathrm{X}_{3} \mathrm{X}_{4}$ & 1845.13 & 1 & 1845.13 & 180.11 & $<0.0001$ \\
$\mathrm{X}_{1}{ }^{2}$ & 72.15 & 1 & 72.15 & 7.04 & 0.0181 \\
$\mathrm{X}_{2}{ }^{2}$ & 7.33 & 1 & 7.33 & 0.72 & 0.4110 \\
$\mathrm{X}_{3}{ }^{2}$ & 205.08 & 1 & 205.08 & 20.02 & 0.0004 \\
$\mathrm{X}_{4}{ }^{2}$ & 651.02 & 1 & 651.02 & 63.55 & $<0.0001$ \\
Residual & 153.66 & 15 & 10.24 & & \\
Lack of Fit & 151.75 & 10 & 15.17 & 39.61 & 0.0004 \\
Pure Error & 1.92 & 5 & 0.38 & & \\
Corrected Total & $16,769.58$ & 29 & & & \\
$\mathrm{R}^{2}$ & 0.9908 & & & & \\
Adjusted $\mathrm{R}^{2}$ & 0.9823 & & & & \\
Adequate & 35.224 & & & & \\
Precision & 4.55 & & & & \\
C.V.\% & & & & \\
\hline
\end{tabular}

\subsection{Interactive Effects of Operational Parameters}

The 3D response surface and 2D contour plots, frequently being applied in other studies [32,33], were provided to demonstrate the interactive influences of selected variables (Figure 3). As shown in Table 5, two interaction term coefficients $\left(X_{1} X_{4}\right.$ and $\left.X_{3} X_{4}\right)$ were significant $(p<0.05,95 \%)$, implying that the interactive effects of relevant operational parameters (nZVI and temperature and $\mathrm{pH}$ and temperature) were crucial for CAP degradation.

Figure 3a,b show nZVI and temperature impacts on the CAP removal efficiency with 3D and 2D methods, respectively. It was clear that the CAP removal rate was mainly dependent on reaction temperature. With the temperature increasing, the CAP degradation efficiency kept increasing in the selected range. Similar phenomena have been frequently observed especially for thermal activation decomposition of organics [43-46]. The $\mathrm{O}-\mathrm{O}$ bond breakage is reasonably enhanced with temperature increase and more $\mathrm{SO}_{4}{ }^{\bullet-}$ could be generated via Equation (4) [45]. In addition, reaction temperature is a crucial variable for aqueous viscosity [29] and the mass transfer coefficient [30]. It has been frequently reported that increasing temperature has a positive effect on pollutant degradation [30,31,47,48]. As for nZVI dosage, the CAP removal efficiency was slightly enhanced by increasing nZVI dosage from $15 \mathrm{mg} / \mathrm{L}$ to $25 \mathrm{mg} / \mathrm{L}$ at $50{ }^{\circ} \mathrm{C}$. On the one hand, nZVI could react with $\mathrm{S}_{2} \mathrm{O}_{8}{ }^{2-}$ to generate $\mathrm{Fe}^{2+}$, which could further activate $\mathrm{S}_{2} \mathrm{O}_{8}{ }^{2-}$ to produce $\mathrm{SO}_{4}{ }^{\bullet-}$ (Equations (5) and (6)) [49-51]. When $\mathrm{Fe}^{2+}$ accumulates in the solution, it could consume $\mathrm{SO}_{4}{ }^{\bullet-}$ via Equation (7) [52]. On the other hand, nZVI could react with dissolved oxygen to generate hydrogen peroxide $\left(\mathrm{H}_{2} \mathrm{O}_{2}\right)$ as an intermediate product and ${ }^{\bullet} \mathrm{OH}$ formation would be found $[17,19,27]$. When nZVI dosage increases, $\mathrm{Fe}^{3+}$ could be reduced to $\mathrm{Fe}^{2+}$ due to the reaction with excessive nZVI via Equation (10) [26]. Then heterogeneous $\mathrm{Fe}^{0}$ activation would be gradually replaced by homogeneous $\mathrm{Fe}^{2+}$ activation along with the reaction process $[26,53]$. Therefore, the degradation enhancement could be ascribed to the greater $\mathrm{Fe}^{2+}$ formation and the larger contact area between $\mathrm{S}_{2} \mathrm{O}_{8}{ }^{2-}$ and nZVI. It is worth mentioning that the CAP degradation efficiency showed a higher value with a low range of nZVI dosage at $70^{\circ} \mathrm{C}$ as demonstrated in Figure $3 a, b$. The phenomenon was probably attributed to the scavenging effect of $\mathrm{Fe}^{2+}$ on $\mathrm{SO}_{4}{ }^{\bullet-}$ via Equation (7). 
At a high temperature, the mass transfer is accelerated and more $\mathrm{Fe}^{2+}$ is generated with a certain dose of nZVI. It was reported that increasing the $\mathrm{Fe}^{2+}$ concentration beyond a value over $300 \mu \mathrm{M}$ would accelerate consumption of $\mathrm{SO}_{4}^{\bullet-}$ [54]. As a result, appropriate nZVI dosage is vital for the CAP degradation efficiency.
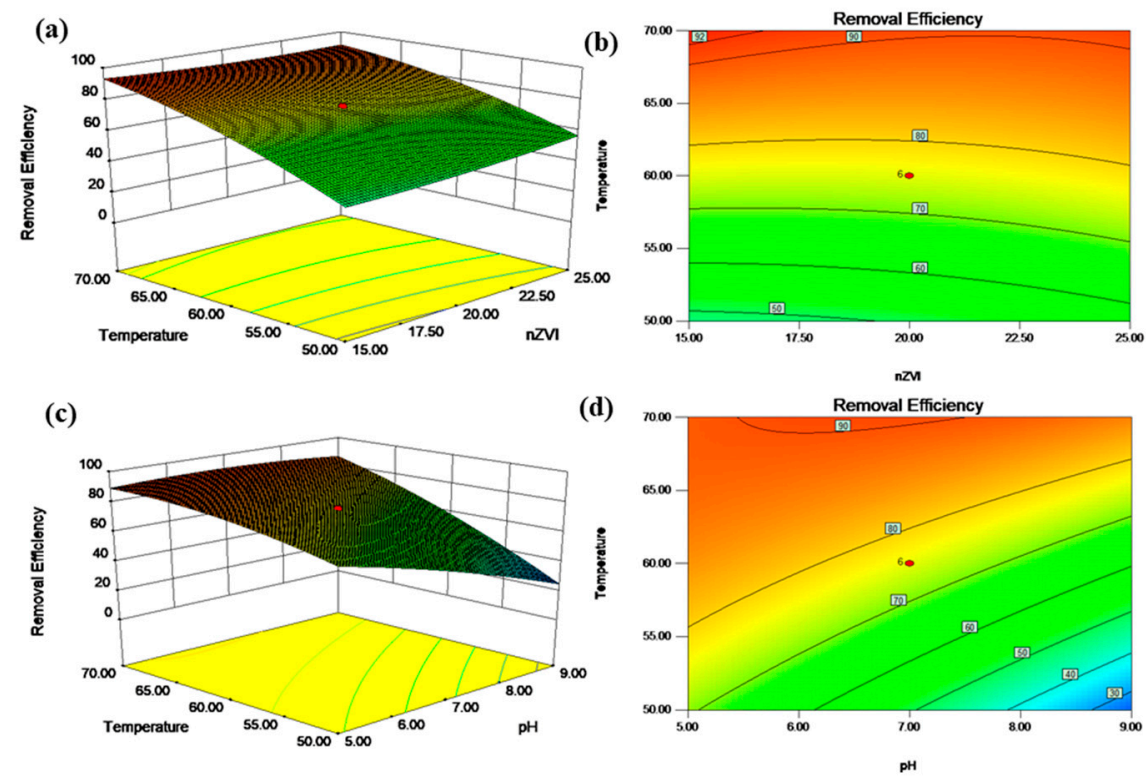

Figure 3. The $3 \mathrm{D}$ response surface and $2 \mathrm{D}$ contour plots of the effects of the interaction on the CAP degradation efficiency (\%). (a) 3D graph of temperature and nZVI, (b) 2D graph of temperature and nZVI, (c) 3D graph of temperature and initial $\mathrm{pH}$, and (d) 2D graph of temperature and nZVI.

$$
\begin{gathered}
\mathrm{S}_{2} \mathrm{O}_{8}{ }^{2-}+\text { heat } \rightarrow 2 \mathrm{SO}_{4}{ }^{\bullet-} \\
\mathrm{S}_{2} \mathrm{O}_{8}{ }^{2-}+\mathrm{Fe}^{0} \rightarrow \mathrm{Fe}^{2+}+2 \mathrm{SO}_{4}{ }^{2-} \\
\mathrm{S}_{2} \mathrm{O}_{8}{ }^{2-}+\mathrm{Fe}^{2+} \rightarrow \mathrm{Fe}^{3+}+\mathrm{SO}_{4}{ }^{2-}+\mathrm{SO}_{4}{ }^{--} \\
\mathrm{SO}_{4}{ }^{\bullet-}+\mathrm{Fe}^{2+} \rightarrow \mathrm{Fe}^{3+}+\mathrm{SO}_{4}{ }^{2-} \\
\mathrm{Fe}^{0}+\mathrm{O}_{2}+2 \mathrm{H}^{+} \rightarrow \mathrm{H}_{2} \mathrm{O}_{2}+\mathrm{Fe}^{2+} \\
\mathrm{H}_{2} \mathrm{O}_{2}+\mathrm{Fe}^{2+} \rightarrow \mathrm{Fe}^{3+}+\cdot \mathrm{OH}+\mathrm{OH}^{-} \\
2 \mathrm{Fe}^{3+}+\mathrm{Fe}^{0} \rightarrow 3 \mathrm{Fe}^{2+} \\
\mathrm{SO}_{4}{ }^{--}+\mathrm{OH}^{-} \rightarrow \mathrm{SO}_{4}{ }^{2-}+\mathrm{HO}^{\bullet}
\end{gathered}
$$

Figure $3 \mathrm{c}, \mathrm{d}$ show $\mathrm{pH}$ and temperature impact on the CAP removal efficiency with $3 \mathrm{D}$ and $2 \mathrm{D}$ methods, respectively. The thermal enhancement has been discussed above. The acidic $\mathrm{pH}$ was more favorable than neutral and alkaline $\mathrm{pH}$ for $\mathrm{CAP}$ removal efficiency at $50^{\circ} \mathrm{C}$, which was evidently due to the enhancement of Equation (8). Increasing $\mathrm{Fe}^{2+}$ could promote the activation of PS (Equation (6)). The amount of soluble $\mathrm{Fe}^{2+}$ decreased at $\mathrm{pH}>4.0$ due to the formation of $\mathrm{Fe}^{2+}$ complexes which hindered the further activation of PS [55]. $\mathrm{SO}_{4}{ }^{\bullet-}$ are rapidly consumed by hydroxyl ions other than $\mathrm{CAP}$ and converted to $\mathrm{HO}^{\bullet}$ at basic conditions, as shown in Equation (11) [6]. On the whole, acidic $\mathrm{pH}$ could promote the CAP degradation based on the increasing $\mathrm{Fe}^{2+}$ activation. When the temperature reached $70{ }^{\circ} \mathrm{C}$, higher removal efficiency was observed in the $\mathrm{pH}$ range of $5.5-7.5$ according to Figure $3 \mathrm{~d}$. Under the circumstance, thermal activation was believed to be the predominant role in the degradation process. The $\mathrm{pH}$ range of 5.5-7.5 was favorable for the maintenance of appropriate $\mathrm{Fe}^{2+}$ concentrations due to $\mathrm{Fe}^{2+}$ shortage in alkaline $\mathrm{pH}$ and the radical scavenging effect of excessive $\mathrm{Fe}^{2+}$ in acidic $\mathrm{pH}$ [56]. 


\subsection{Fe-Speciation Analysis}

To reveal the Fe-containing species of mixed powder after reaction, XPS was employed to analyze the Fe species under the optimal condition (Figure 4). Based on the binding energies of peaks, it could be inferred that $\mathrm{Fe}_{2} \mathrm{O}_{3}$ and $\mathrm{Fe}_{3} \mathrm{O}_{4}$ were the predominant components in mixed powder. The binding energy of $\mathrm{Fe} 2 \mathrm{p}_{1 / 2}$ of $\mathrm{Fe}_{2} \mathrm{O}_{3}$ was reported to be $724.6 \mathrm{eV}$ [57,58], indicating that Peak A was the spectra of $\mathrm{Fe}_{2} \mathrm{O}_{3}$. Peak $\mathrm{B}$ located in the binding energy of $718.3 \mathrm{eV}$, which could be considered as the satellite peak for Fe $2 p_{1 / 2}[57,58]$. Peak $\mathrm{C}$ was $713.4 \mathrm{eV}$, which was believed to be $\mathrm{Fe}_{3} \mathrm{O}_{4}$ according to previous studies $[58,59]$. Based on the binding energy and cover ratio, Peak D could be inferred as $\mathrm{Fe}_{3} \mathrm{O}_{4}$, which is consistent with the existing studies [59,60]. In addition, Peaks $\mathrm{E}$ and $\mathrm{F}$ being located in $711.2 \mathrm{eV}$ and $709.8 \mathrm{eV}$ could be considered as $\mathrm{Fe}_{3} \mathrm{O}_{4}$ and $\mathrm{Fe}_{2} \mathrm{O}_{3}$, respectively [58,61]. Overall, $\mathrm{Fe}_{2} \mathrm{O}_{3}$ and $\mathrm{Fe}_{3} \mathrm{O}_{4}$ were the predominant components in mixed powder.

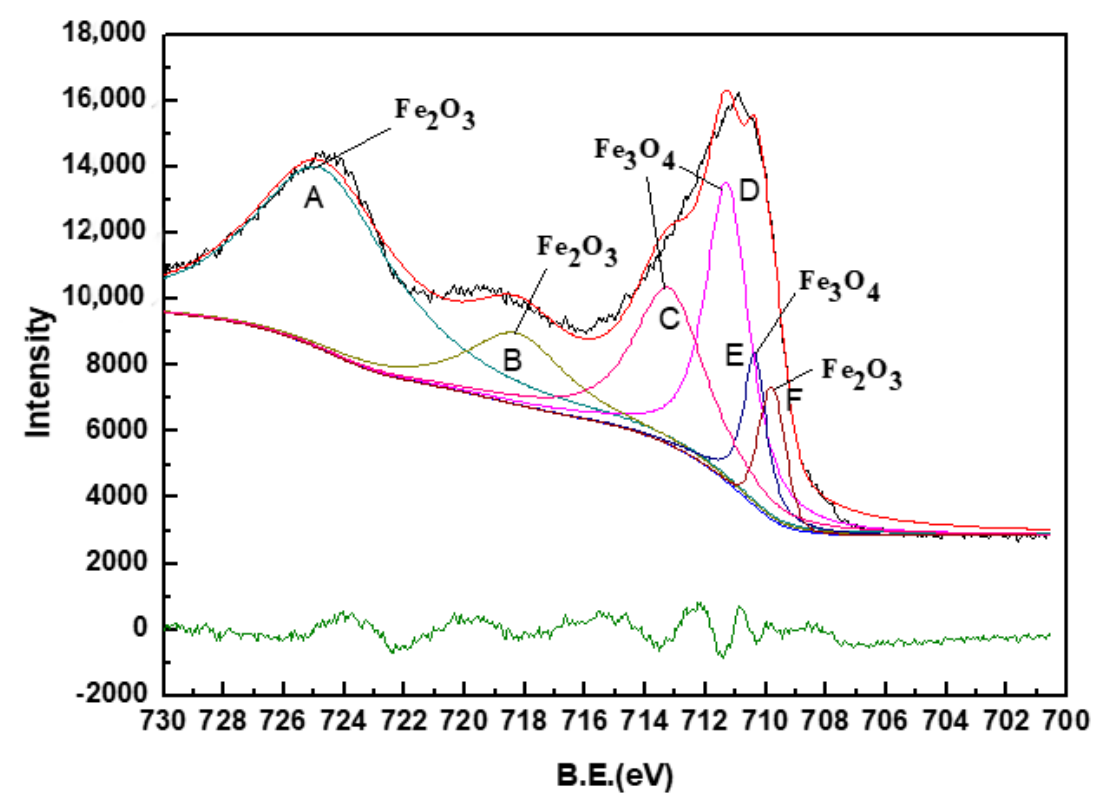

Figure 4. The X-ray photoelectron spectroscopy (XPS) spectrum of nZVI surface after reactions.

Furthermore, the XRD patterns of the crystalline structure on nZVI surface before and after reactions are demonstrated in Figure 5. Sharp reflection peaks at $44.87^{\circ}$ and $65.24^{\circ}$ could be indexed as the planes of $\mathrm{Fe}^{0}$ (PDF\#65-4899). Thus, the nZVI sample before reactions was of high purity in iron content. Even after reactions, excess $\mathrm{Fe}^{0}$ was observed in the system. In addition to $\mathrm{Fe}^{0}$, the XRD patterns of $\mathrm{Fe}_{3} \mathrm{O}_{4}$ (PDF\#65-3107) and $\mathrm{Fe}_{2} \mathrm{O}_{3}$ (PDF\#39-1346) fit well with the crystalline structure after reactions. It is worth mentioning that the planes of $\mathrm{Fe}_{3} \mathrm{O}_{4}$ (PDF\#65-3107) and $\mathrm{Fe}_{2} \mathrm{O}_{3}$ (PDF\#39-1346) showed high similarity in major reflection peaks, probably because stoichiometric $\mathrm{Fe}_{3} \mathrm{O}_{4}$ could also be expressed to $\mathrm{FeO} \cdot \mathrm{Fe}_{2} \mathrm{O}_{3}$ with the $\mathrm{Fe}^{2+}: \mathrm{Fe}^{3+}$ ratio of 1:2 [57]. The XRD results were in line with those of XPS analysis. 


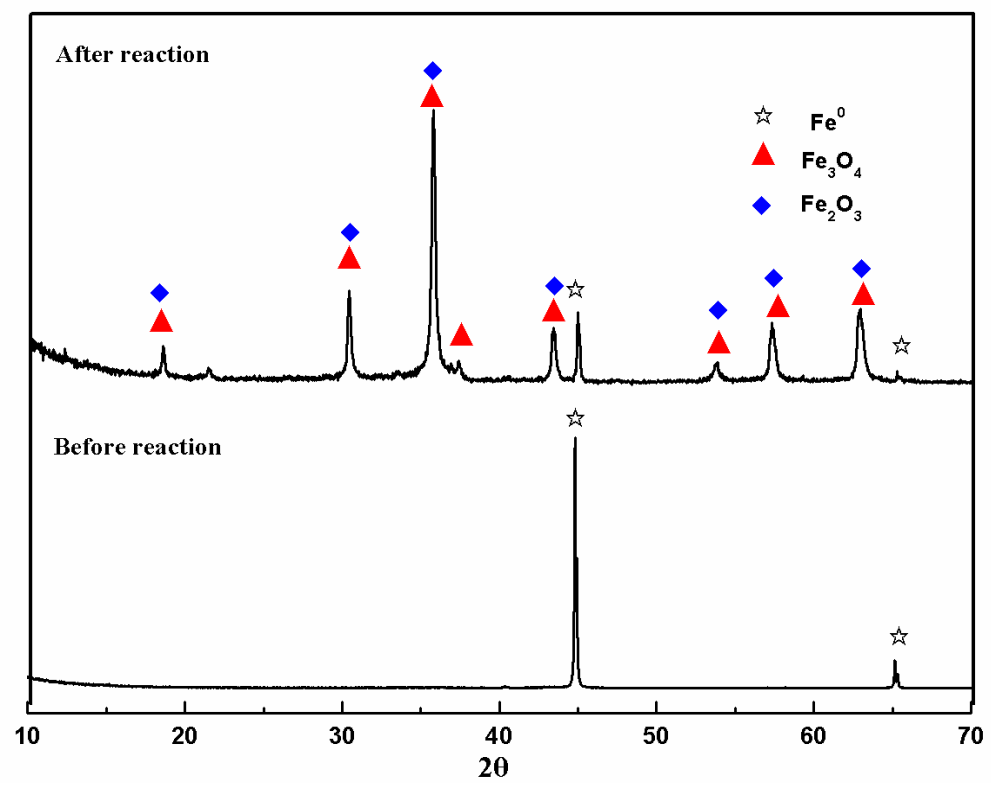

Figure 5. X-ray diffraction (XRD) spectra of solid powders before and after reactions.

Since the optimal $\mathrm{pH}$ was in the range of 5.5-7.5, the precipitation of $\mathrm{Fe}^{3+}$ ions occurred whenever the $\mathrm{pH}>4.0$ [56] and $\mathrm{FeOOH}$ and $\mathrm{Fe}_{3} \mathrm{O}_{4}$ may be produced via a series of reactions Equations (12)-(14) [26]. Meanwhile $\mathrm{Fe}^{2+}(\mathrm{s})$ in magnetite contributed to persulfate activation by donating electrons [26,62]. Furthermore, $\mathrm{FeOOH}$ was believed to react with $\mathrm{Fe}^{0}$ to generate $\mathrm{Fe}_{3} \mathrm{O}_{4}$ due to no FeOOH being found in this study. Meanwhile, it has been demonstrated that $\mathrm{Fe}(\mathrm{OH})_{3}$ can produce the mixture of $\mathrm{FeOOH}$ and $\alpha-\mathrm{Fe}_{2} \mathrm{O}_{3}$ at the range of $40-80{ }^{\circ} \mathrm{C}$ (Equation (15)) $[63,64]$. $\mathrm{FeOOH}$ could be converted to $\mathrm{Fe}_{2} \mathrm{O}_{3}$ due to poor chemical stability (Equation (16)) [63]. $\mathrm{Fe}_{3} \mathrm{O}_{4}$ and $\mathrm{Fe}_{2} \mathrm{O}_{3}$ were both reported in previous persulfate activation investigations $[65,66]$, thus, it could be induced that $\mathrm{Fe}_{3} \mathrm{O}_{4}$ and $\mathrm{Fe}_{2} \mathrm{O}_{3}$ gradually become the persulfate activators. $\mathrm{Fe}_{3} \mathrm{O}_{4}$ and $\mathrm{Fe}_{2} \mathrm{O}_{3}$ on the surface of nZVI slacken the release of $\mathrm{Fe}^{2+}$ from nZVI, eliminating the scavenging effects of $\mathrm{Fe}^{2+}$ on sulfate radicals. After the treatment, there might be $\mathrm{Fe}^{3+}$ or $\mathrm{Fe}^{2+}$ in the treated effluent. Therefore, alkaline $\mathrm{pH}$ is necessary for the treated effluent to remove $\mathrm{Fe}^{3+}$ and $\mathrm{Fe}^{2+}$ by precipitation formation.

$$
\begin{gathered}
\mathrm{Fe}^{3+}+3 \mathrm{OH}^{-} \rightarrow \mathrm{Fe}(\mathrm{OH})_{3(\mathrm{~s})} \\
\mathrm{Fe}^{2+}+2 \mathrm{H}_{2} \mathrm{O} \leftrightarrow \mathrm{FeOOH}_{(\mathrm{s})}+3 \mathrm{H}^{+} \\
8 \mathrm{FeOOH}_{(\mathrm{s})}+\mathrm{Fe}^{0} \rightarrow 3 \mathrm{Fe}_{3} \mathrm{O}_{4(\mathrm{~s})}+4 \mathrm{H}_{2} \mathrm{O} \\
2 \mathrm{Fe}(\mathrm{OH})_{3(\mathrm{~s})} \rightarrow \alpha-\mathrm{Fe}_{2} \mathrm{O}_{3}+3 \mathrm{H}_{2} \mathrm{O} \\
2 \alpha-\mathrm{FeOOH}_{(\mathrm{s})}+\rightarrow \alpha-\mathrm{Fe}_{2} \mathrm{O}_{3}+\mathrm{H}_{2} \mathrm{O}
\end{gathered}
$$

\subsection{Optimization of Removal Process}

Optimization treatment was carried out by numerical technique built in Design Expert 8.0.6 [33]. The optimum values of parameters required to obtain the highest CAP removal were obtained. The goals for the parameters (initial $\mathrm{pH}, \mathrm{nZVI}$ dosage, temperature, and PS concentration) were set as "in range", while $Y$ was set as "maximize". And then the equation (Equation (3)) was employed as a predicting tool to calculate and provide the optimal conditions. The optimum solution was selected based on economic considerations and availability and cost of reagents and energy [36]. Based on these principles, the model provided the optimal variable values of $15 \mathrm{mg} / \mathrm{L}, 0.5 \mathrm{mmol} / \mathrm{L}, 7.08$, and $70{ }^{\circ} \mathrm{C}$ for nZVI dosage, PS, initial $\mathrm{pH}$, and temperature, respectively, with $97.12 \%$ of degradation efficiency. Eventually, an extra experiment was performed under the mentioned variables for accuracy 
confirmation. An excellent decomposition efficiency (average removal of $98.32 \%$ with triplicate) was observed, which was in proximity to the predicted efficiency. The main concern of the process is the need for relatively high temperature $\left(70^{\circ} \mathrm{C}\right)$ because of the cost of treating large volumes of wastewater. More real conditions need to be considered in future work to evaluate the operational cost.

\section{Conclusions}

In this study, Design Expert 8.0 was employed to optimize the operational variables for CAP removal in a "heat + nZVI + PS" system. The combined activated PS degradation of CAP showed a synergistic index of 1.43, indicating an excellent performance of nZVI-heat activation. A 4-factor, 5-level CCD design based on RSM was carried out for the experiments. A quadratic model with high correlation coefficients $\left(\mathrm{R}^{2}\right.$ adj $\left.=0.9823\right)$ was established to predict the CAP degradation efficiency. The influences of selected variables (initial pH, PS concentration, nZVI, and temperature) and their interactions were assessed and summarized using ANOVA. Subsequently, the optimized experimental conditions for CAP removal in this study were predicted by the quadratic model of $15 \mathrm{mg} / \mathrm{L}, 0.5 \mathrm{mmol} / \mathrm{L}$, 7.08 , and $70{ }^{\circ} \mathrm{C}$ for nZVI dosage, PS, initial $\mathrm{pH}$, and temperature, respectively, for $97.12 \%$ of CAP removal. Under the optimum conditions, average removal of $98.32 \%$ with triplicate was achieved, which was in proximity to the predicted efficiency. In addition, Fe-speciation analysis was conducted to reveal the actual composition of mixed powders of $\mathrm{Fe}_{2} \mathrm{O}_{3}$ and $\mathrm{Fe}_{3} \mathrm{O}_{4}$ after reactions, which could also act as the activators along with the reaction. Overall, it could be concluded that the nZVI-heat activation of PS was an efficient technique for CAP degradation.

Author Contributions: Writing—original draft, L.Y.; investigation, H.L.; writing—review and editing, resources, J.X.; investigation, L.H.; data curation, Y.M.; supervision, L.W.; writing-review and editing, project administration, Z.Z. All authors have read and agreed to the published version of the manuscript.

Funding: This work was financially supported by the Changjiang River Scientific Research Institute (CRSRI) Open Research Program (Program SN: CKWV2019771/KY), National Natural Science Foundation of China (No. 51878523, No. U1703120, and No. 51508430), the Recruitment Program of Global Experts (Young Professionals), the Fundamental Research Funds for the Central Universities (WUT:193108003, 2019IVA032) and the Scottish Government's Rural and Environment Science and Analytical Service Division (RESAS).

Conflicts of Interest: The authors declare no conflict of interest.

\section{References}

1. Podzelinska, K.; Latimer, R.; Bhattacharya, A.; Vining, L.C.; Zechel, D.L.; Jia, Z. Chloramphenicol Biosynthesis: The Structure of CmlS, a Flavin-Dependent Halogenase Showing a Covalent Flavin-Aspartate Bond. J. Mol. Biol. 2010, 397, 316-331. [CrossRef]

2. Samsonova, J.V.; Cannavan, A.; Elliott, C.T. A Critical Review of Screening Methods for the Detection of Chloramphenicol, Thiamphenicol, and Florfenicol Residues in Foodstuffs. Crit. Rev. Anal. Chem. 2012, 42, 50-78. [CrossRef]

3. Ma, W.; Dai, J.; Dai, X.; Da, Z.; Yan, Y. Core-shell molecularly imprinted polymers based on magnetic chitosan microspheres for chloramphenicol selective adsorption. Mon. Chem. Chem. Mon. 2015, 146, 465-474. [CrossRef]

4. Kramer, W.G.; Rensimer, E.R.; Ericsson, C.D.; Pickering, L.K. Comparative Bioavailability of Intravenous and Oral Chloramphenicol in Adults. J. Clin. Pharmacol. 1984, 24, 181-186. [CrossRef]

5. Choi, K.; Kim, Y.; Jung, J.; Kim, M.H.; Kim, C.S.; Kim, N.H.; Park, J. Occurrences and ecological risks of roxithromycin, trimethoprim, and chloramphenicol in the Han River, Korea. Environ. Toxicol. Chem. 2008, 27, 711-719. [CrossRef]

6. Nie, M.H.; Yang, Y.; Zhang, Z.J.; Yan, C.X.; Wang, X.N.; Li, H.J.; Dong, W.B. Degradation of chloramphenicol by thermally activated persulfate in aqueous solution. Chem. Eng. J. 2014, 246, 373-382. [CrossRef]

7. Jiang, L.; Hu, X.; Yin, D.; Zhang, H.; Yu, Z. Occurrence, distribution and seasonal variation of antibiotics in the Huangpu River, Shanghai, China. Chemosphere 2011, 82, 822-828. [CrossRef]

8. Badawy, M.I.; Wahaab, R.A.; El-Kalliny, A.S. Fenton-biological treatment processes for the removal of some pharmaceuticals from industrial wastewater. J. Hazard. Mater. 2009, 167, 567-574. [CrossRef] 
9. Chu, W.H.; Chu, T.F.; Du, E.D.; Yang, D.; Guo, Y.Q.; Gao, N.Y. Increased formation of halomethanes during chlorination of chloramphenicol in drinking water by UV irradiation, persulfate oxidation, and combined UV/persulfate pre-treatments. Ecotox. Environ. Safe 2016, 124, 147-154. [CrossRef]

10. Shokri, M.; Jodat, A.; Modirshahla, N.; Behnajady, M.A. Photocatalytic degradation of chloramphenicol in an aqueous suspension of silver-doped $\mathrm{TiO}_{2}$ nanoparticles. Environ. Technol. 2013, 34, 1161-1166. [CrossRef]

11. Fan, Y.; Wang, B.; Yuan, S.; Wu, X.; Chen, J.; Wang, L. Adsorptive removal of chloramphenicol from wastewater by $\mathrm{NaOH}$ modified bamboo charcoal. Bioresour. Technol. 2010, 101, 7661-7664. [CrossRef]

12. Dai, J.; He, J.; Xie, A.; Gao, L.; Pan, J.; Chen, X.; Zhou, Z.; Wei, X.; Yan, Y. Novel pitaya-inspired well-defined core-shell nanospheres with ultrathin surface imprinted nanofilm from magnetic mesoporous nanosilica for highly efficient chloramphenicol removal. Chem. Eng. J. 2016, 284, 812-822. [CrossRef]

13. Qin, L.; Zhou, Z.; Dai, J.; Ma, P.; Zhao, H.; He, J.; Xie, A.; Li, C.; Yan, Y. Novel N-doped hierarchically porous carbons derived from sustainable shrimp shell for high-performance removal of sulfamethazine and chloramphenicol. J. Taiwan Inst. Chem. Eng. 2016, 62, 228-238. [CrossRef]

14. Tran, V.S.; Ngo, H.H.; Guo, W.; Ton-That, C.; Li, J.; Li, J.; Liu, Y. Removal of antibiotics (sulfamethazine, tetracycline and chloramphenicol) from aqueous solution by raw and nitrogen plasma modified steel shavings. Sci. Total Environ. 2017, 601, 845-856. [CrossRef]

15. Dai, J.; Tian, S.; Jiang, Y.; Chang, Z.; Xie, A.; Zhang, R.; Yan, Y. Facile synthesis of porous carbon sheets from potassium acetate via in-situ template and self-activation for highly efficient chloramphenicol removal. J. Alloys Compd. 2018, 732, 222-232. [CrossRef]

16. Singh, K.P.; Singh, A.K.; Gupta, S.; Rai, P. Modeling and optimization of reductive degradation of chloramphenicol in aqueous solution by zero-valent bimetallic nanoparticles. Environ. Sci. Pollut. $R$ 2012, 19, 2063-2078. [CrossRef]

17. Xia, S.; Gu, Z.; Zhang, Z.; Zhang, J.; Hermanowicz, S.W. Removal of chloramphenicol from aqueous solution by nanoscale zero-valent iron particles. Chem. Eng. J. 2014, 257, 98-104. [CrossRef]

18. Liu, X.; Cao, Z.; Yuan, Z.L.; Zhang, J.; Guo, X.P.; Yang, Y.; He, F.; Zhao, Y.P.; Xu, J. Insight into the kinetics and mechanism of removal of aqueous chlorinated nitroaromatic antibiotic chloramphenicol by nanoscale zero-valent iron. Chem. Eng. J. 2018, 334, 508-518. [CrossRef]

19. Wu, Y.W.; Yue, Q.Y.; Ren, Z.F.; Gao, B.Y. Immobilization of nanoscale zero-valent iron particles (nZVI) with synthesized activated carbon for the adsorption and degradation of Chloramphenicol (CAP). J. Mol. Liq. 2018, 262, 19-28. [CrossRef]

20. Cotillas, S.; Lacasa, E.; Sáez, C.; Cañizares, P.; Rodrigo, M.A. Electrolytic and electro-irradiated technologies for the removal of chloramphenicol in synthetic urine with diamond anodes. Water Res. 2018, 128, 383-392. [CrossRef]

21. Guo, N.; Wang, Y.K.; Yan, L.; Wang, X.H.; Wang, M.Y.; Xu, H.; Wang, S.G. Effect of bio-electrochemical system on the fate and proliferation of chloramphenicol resistance genes during the treatment of chloramphenicol wastewater. Water Res. 2017, 117, 95-101. [CrossRef]

22. Devi, P.; Das, U.; Dalai, A.K. In-situ chemical oxidation: Principle and applications of peroxide and persulfate treatments in wastewater systems. Sci. Total Environ. 2016, 571, 643-657. [CrossRef]

23. Wacławek, S.; Lutze, H.V.; Grübel, K.; Padil, V.V.T.; Černík, M.; Dionysiou, D.D. Chemistry of persulfates in water and wastewater treatment: A review. Chem. Eng. J. 2017, 330, 44-62. [CrossRef]

24. Miklos, D.B.; Remy, C.; Jekel, M.; Linden, K.G.; Drewes, J.E.; Hübner, U. Evaluation of advanced oxidation processes for water and wastewater treatment-A critical review. Water Res. 2018, 139, 118-131. [CrossRef]

25. Matzek, L.W.; Carter, K.E. Activated persulfate for organic chemical degradation: A review. Chemosphere 2016, 151, 178-188. [CrossRef]

26. Kim, C.; Ahn, J.-Y.; Kim, T.Y.; Shin, W.S.; Hwang, I. Activation of Persulfate by Nanosized Zero-Valent Iron (NZVI): Mechanisms and Transformation Products of NZVI. Environ. Sci. Technol. 2018, 52, 3625-3633. [CrossRef]

27. Fu, Y.; Peng, L.; Zeng, Q.; Yang, Y.; Song, H.; Shao, J.; Liu, S.; Gu, J. High efficient removal of tetracycline from solution by degradation and flocculation with nanoscale zerovalent iron. Chem. Eng. J. 2015, 270, 631-640. [CrossRef]

28. Karim, S.; Bae, S.; Greenwood, D.; Hanna, K.; Singhal, N. Degradation of $17 \alpha$-ethinylestradiol by nano zero valent iron under different $\mathrm{pH}$ and dissolved oxygen levels. Water Res. 2017, 125, 32-41. [CrossRef] 
29. Hou, L.; Wang, L.; Royer, S.; Zhang, H. Ultrasound-assisted heterogeneous Fenton-like degradation of tetracycline over a magnetite catalyst. J. Hazard Mater. 2016, 302, 458-467. [CrossRef]

30. Liu, F.Z.; Yi, P.; Wang, X.; Gao, H.; Zhang, H. Degradation of Acid Orange 7 by an ultrasound/ZnO-GAC/persulfate process. Sep. Purif. Technol. 2018, 194, 181-187. [CrossRef]

31. Zou, X.L.; Zhou, T.; Mao, J.; Wu, X.H. Synergistic degradation of antibiotic sulfadiazine in a heterogeneous ultrasound-enhanced Fe-0/persulfate Fenton-like system. Chem. Eng. J. 2014, 257, 36-44. [CrossRef]

32. Safari, G.H.; Nasseri, S.; Mahvi, A.H.; Yaghmaeian, K.; Nabizadeh, R.; Alimohammadi, M. Optimization of sonochemical degradation of tetracycline in aqueous solution using sono-activated persulfate process. J. Environ. Health Sci. Eng. 2015, 13, 76. [CrossRef] [PubMed]

33. Eslami, A.; Asadi, A.; Meserghani, M.; Bahrami, H. Optimization of sonochemical degradation of amoxicillin by sulfate radicals in aqueous solution using response surface methodology (RSM). J. Mol. Liq. 2016, 222, 739-744. [CrossRef]

34. Li, R.B.; Cai, M.X.; Liu, H.J.; Liu, G.G.; Lv, W.Y. Thermo-activated peroxydisulfate oxidation of indomethacin: Kinetics study and influences of co-existing substances. Chemosphere 2018, 212, 1067-1075. [CrossRef]

35. Tan, C.Q.; Fu, D.F.; Gao, N.Y.; Qin, Q.D.; Xu, Y.; Xiang, H.M. Kinetic degradation of chloramphenicol in water by UV/persulfate system. J. Photochem. Photobiol. A Chem. 2017, 332, 406-412. [CrossRef]

36. Bahrami, H.; Eslami, A.; Nabizadeh, R.; Mohseni-Bandpi, A.; Asadi, A.; Sillanpaa, M. Degradation of trichloroethylene by sonophotolytic-activated persulfate processes: Optimization using response surface methodology. J. Clean Prod. 2018, 198, 1210-1218. [CrossRef]

37. Durán, A.; Monteagudo, J.M.; Expósito, A.J.; Monsalve, V. Modeling the sonophoto-degradation/ mineralization of carbamazepine in aqueous solution. Chem. Eng. J. 2016, 284, 503-512. [CrossRef]

38. Kusic, H.; Peternel, I.; Koprivanac, N.; Bozic, A.L. Iron-Activated Persulfate Oxidation of an Azo Dye in Model Wastewater: Influence of Iron Activator Type on Process Optimization. J. Environ. Eng. 2011, 137, 454-463. [CrossRef]

39. Turan, M.D.; Arslanoğlu, H.; Altundoğan, H.S. Optimization of the leaching conditions of chalcopyrite concentrate using ammonium persulfate in an autoclave system. J. Taiwan Inst. Chem. Eng. 2015, 50, 49-55. [CrossRef]

40. Yang, Q.; Zhong, Y.; Zhong, H.; Li, X.; Du, W.; Li, X.; Chen, R.; Zeng, G. A novel pretreatment process of mature landfill leachate with ultrasonic activated persulfate: Optimization using integrated Taguchi method and response surface methodology. Process Saf. Environ. Prot. 2015, 98, 268-275. [CrossRef]

41. Tripathy, B.K.; Ramesh, G.; Debnath, A.; Kumar, M. Mature landfill leachate treatment using sonolytic-persulfate/hydrogen peroxide oxidation: Optimization of process parameters. Ultrason. Sonochem. 2019, 54, 210-219. [CrossRef]

42. Abu Amr, S.S.; Aziz, H.A.; Adlan, M.N. Optimization of stabilized leachate treatment using ozone/persulfate in the advanced oxidation process. Waste Manag. 2013, 33, 1434-1441. [CrossRef]

43. Chen, X.; Murugananthan, M.; Zhang, Y. Degradation of p-Nitrophenol by thermally activated persulfate in soil system. Chem. Eng. J. 2016, 283, 1357-1365. [CrossRef]

44. Yang, J.F.; Yang, L.M.; Zhang, S.B.; Ou, L.H.; Liu, C.B.; Zheng, L.Y.; Yang, Y.F.; Ying, G.G.; Luo, S.L. Degradation of azole fungicide fluconazole in aqueous solution by thermally activated persulfate. Chem. Eng. J. 2017, 321, 113-122. [CrossRef]

45. Cai, J.; Zhou, M.; Yang, W.; Pan, Y.; Lu, X.; Serrano, K.G. Degradation and mechanism of 2,4-dichlorophenoxyacetic acid (2,4-D) by thermally activated persulfate oxidation. Chemosphere 2018, 212, 784-793. [CrossRef]

46. Chen, J.; Qian, Y.; Liu, H.; Huang, T. Oxidative degradation of diclofenac by thermally activated persulfate: implication for ISCO. Environ. Sci. Pollut. R 2016, 23, 3824-3833. [CrossRef]

47. Nasseri, S.; Mahvi, A.H.; Seyedsalehi, M.; Yaghmaeian, K.; Nabizadeh, R.; Alimohammadi, M.; Safari, G.H. Degradation kinetics of tetracycline in aqueous solutions using peroxydisulfate activated by ultrasound irradiation: Effect of radical scavenger and water matrix. J. Mol. Liq. 2017, 241, 704-714. [CrossRef]

48. Zhu, J.; Li, B.Z. Degradation Kinetic and Remediation Effectiveness of 1,4-Dioxane-Contaminated Groundwater by a Sono-Activated Persulfate Process. J. Environ. Eng. 2018, 144, 04018098. [CrossRef]

49. Rodriguez, S.; Vasquez, L.; Costa, D.; Romero, A.; Santos, A. Oxidation of Orange G by persulfate activated by $\mathrm{Fe}(\mathrm{II}), \mathrm{Fe}(\mathrm{III})$ and zero valent iron (ZVI). Chemosphere 2014, 101, 86-92. [CrossRef] 
50. Tan, C.Q.; Dong, Y.J.; Fu, D.F.; Gao, N.Y.; Ma, J.X.; Liu, X.Y. Chloramphenicol removal by zero valent iron activated peroxymonosulfate system: Kinetics and mechanism of radical generation. Chem. Eng. J. 2018, 334, 1006-1015. [CrossRef]

51. Lu, L.L.; Zhai, P.P.; Chen, X.; Li, H.J.; Chovelon, J.M. Degradation of p-Aminobenzoic Acid by Zero-Valent Iron Activated Persulfate System. J. Environ. Eng. 2018, 144. [CrossRef]

52. Vicente, F.; Santos, A.; Romero, A.; Rodriguez, S. Kinetic study of diuron oxidation and mineralization by persulphate: Effects of temperature, oxidant concentration and iron dosage method. Chem. Eng. J. 2011, 170, 127-135. [CrossRef]

53. Nie, M.H.; Yan, C.X.; Li, M.; Wang, X.N.; Bi, W.L.; Dong, W.B. Degradation of chloramphenicol by persulfate activated by $\mathrm{Fe} 2+$ and zerovalent iron. Chem. Eng. J. 2015, 279, 507-515. [CrossRef]

54. Lin, H.; Wu, J.; Zhang, H. Degradation of clofibric acid in aqueous solution by an $\mathrm{EC} / \mathrm{Fe}^{3+} / \mathrm{PMS}^{\text {process. }}$ Chem. Eng. J. 2014, 244, 514-521. [CrossRef]

55. Stefánsson, A. Iron(III) Hydrolysis and Solubility at $25^{\circ} \mathrm{C}$. Environ. Sci. Technol. 2007, 41, 6117-6123. [CrossRef]

56. Xu, X.-R.; Li, X.-Z. Degradation of azo dye Orange $\mathrm{G}$ in aqueous solutions by persulfate with ferrous ion. Sep. Purif. Technol. 2010, 72, 105-111. [CrossRef]

57. Yamashita, T.; Hayes, P. Analysis of XPS spectra of $\mathrm{Fe}^{2+}$ and $\mathrm{Fe}^{3+}$ ions in oxide materials. Appl. Surf. Sci. 2008, 254, 2441-2449. [CrossRef]

58. Cao, Z.; Liu, X.; Xu, J.; Zhang, J.; Yang, Y.; Zhou, J.; Xu, X.; Lowry, G.V. Removal of Antibiotic Florfenicol by Sulfide-Modified Nanoscale Zero-Valent Iron. Environ. Sci. Technol. 2017, 51, 11269-11277. [CrossRef]

59. Biesinger, M.C.; Payne, B.P.; Grosvenor, A.P.; Lau, L.W.M.; Gerson, A.R.; Smart, R.S.C. Resolving surface chemical states in XPS analysis of first row transition metals, oxides and hydroxides: $\mathrm{Cr}, \mathrm{Mn}, \mathrm{Fe}, \mathrm{Co}$ and Ni. Appl. Surf. Sci. 2011, 257, 2717-2730. [CrossRef]

60. Lin, T.-C.; Seshadri, G.; Kelber, J.A. A consistent method for quantitative XPS peak analysis of thin oxide films on clean polycrystalline iron surfaces. Appl. Surf. Sci. 1997, 119, 83-92. [CrossRef]

61. Grosvenor, A.P.; Kobe, B.A.; Biesinger, M.C.; McIntyre, N.S. Investigation of multiplet splitting of Fe 2p XPS spectra and bonding in iron compounds. Surf. Interface Anal. 2004, 36, 1564-1574. [CrossRef]

62. Xu, J.; Zhang, X.; Sun, C.; Wan, J.; He, H.; Wang, F.; Dai, Y.; Yang, S.; Lin, Y.; Zhan, X. Insights into removal of tetracycline by persulfate activation with peanut shell biochar coupled with amorphous $\mathrm{Cu}$-doped $\mathrm{FeOOH}$ composite in aqueous solution. Environ. Sci. Pollut. R 2019, 26, 2820-2834. [CrossRef] [PubMed]

63. Xiong, H.-X.; Zhou, L.-X. Synthesis of iron oxyhydroxides of different crystal forms and their roles in adsorption and removal of $\mathrm{Cr}(\mathrm{VI})$ from aqueous solutions. Acta Petrol. ET Mineral. 2008, 27, 559-566.

64. Yang, L.; He, L.; Xue, J.; Wu, L.; Ma, Y.; Li, H.; Peng, P.; Li, M.; Zhang, Z. Highly efficient nickel (II) removal by sewage sludge biochar supported $\alpha-\mathrm{Fe}_{2} \mathrm{O}_{3}$ and $\alpha-\mathrm{FeOOH}$ : Sorption characteristics and mechanisms. PLoS ONE 2019, 14, e0218114. [CrossRef] [PubMed]

65. Yan, J.; Lei, M.; Zhu, L.; Anjum, M.N.; Zou, J.; Tang, H. Degradation of sulfamonomethoxine with Fe3O4 magnetic nanoparticles as heterogeneous activator of persulfate. J. Hazard. Mater. 2011, 186, 1398-1404. [CrossRef] [PubMed]

66. Kermani, M.; Mohammadi, F.; Kakavandi, B.; Esrafili, A.; Rostamifasih, Z. Simultaneous catalytic degradation of 2,4-D and MCPA herbicides using sulfate radical-based Heterog oxidation over persulfate activated by natural hematite ( $\left.\alpha-\mathrm{Fe}_{2} \mathrm{O}_{3} / \mathrm{PS}\right)$. J. Phys. Chem. Solids 2018, 117, 49-59. [CrossRef]

(C) 2019 by the authors. Licensee MDPI, Basel, Switzerland. This article is an open access article distributed under the terms and conditions of the Creative Commons Attribution (CC BY) license (http://creativecommons.org/licenses/by/4.0/). 